\title{
Acute effect of green tea catechins on uric acid metabolism after alcohol ingestion in Japanese men
}

\section{Yuka Kawakami ( $\sim$ kawakami@u-shizuoka-ken.ac.jp )}

The University of Shizuoka https://orcid.org/0000-0003-0054-9872

\section{Arisa Yasuda}

The University of Shizuoka

Motoki Hayashi

The University of Shizuoka

\section{Misuzu Akiyama}

The University of Shizuoka

\section{Toshihiko Asai}

Asai Clinic

\section{Toshio Hosaka}

The University of Shizuoka

\section{Hidekazu Arai}

The University of Shizuoka

\section{Research}

Keywords: hyperuricemia, green tea catechins, xanthine, hypoxanthine, alcohol ingestion

Posted Date: September 25th, 2020

DOl: https://doi.org/10.21203/rs.3.rs-22189/v3

License: (9) This work is licensed under a Creative Commons Attribution 4.0 International License. Read Full License

Version of Record: A version of this preprint was published at Clinical Rheumatology on February 10th, 2021. See the published version at https://doi.org/10.1007/s10067-021-05625-7. 


\section{Abstract}

Objective: Alcohol consumption is associated with hyperuricemia and gout. Previous studies have indicated a role for green tea catechins in uric acid (UA) metabolism. This study aimed to elucidate the acute effect of green tea catechins in terms of enhancing urinary excretion of UA and xanthine/hypoxanthine (Xa/HX; UA precursors) after alcohol ingestion.

Methods: In a randomized crossover study, ten healthy Japanese subjects consumed test meals, including a Japanese distilled spirit (Shōchū) with water (SW) or Shōchū with catechin-rich green tea (SC), each containing $20 \mathrm{~g}$ of alcohol. The SC contained $617 \mathrm{mg}$ of catechin in total. Serum and urine UA and $\mathrm{Xa} / \mathrm{HX}$ concentrations were measured. Blood samples were collected after $2.5 \mathrm{~h}$, and urine samples were collected between 0 and $5 \mathrm{~h}$ after consuming the test meal.

Results: Urine UA and $\mathrm{Xa} / \mathrm{HX}$ excretions were significantly higher in the SC group than in the SW group. UA clearance and fractional UA excretion tended to increase more in the SC group than in the SW group. No significant differences in serum $\mathrm{UA}$ and $\mathrm{Xa} / \mathrm{HX}$ concentrations were observed between two groups.

Conclusions: It was concluded that green tea catechins can enhance the excretion of UA and $\mathrm{Xa} / \mathrm{HX}$, even though alcohol is ingested.

\section{Introduction}

Hyperuricemia, which is the main risk factor for gout, is defined as serum uric acid (UA) concentration of $\geq 7 \mathrm{mg} / \mathrm{dL}$. The prevalence rates of hyperuricemia and gout continue to increase. ${ }^{(1)}$ Moreover, hyperuricemia is also closely associated with metabolic syndrome, chronic kidney disease, and cardiovascular disease. ${ }^{(2-6)}$ Several studies have reported that lifestyle factors, including alcohol, purinerich foods, and fructose are associated with the development of hyperuricemia and gout. ${ }^{(7,8)}$ Thus, lifestyle improvement may be important for preventing hyperuricemia.

Alcohol consumption has been associated with the development of gout. ${ }^{(9)}$ Adenosine triphosphate (ATP) is consumed during alcohol metabolism, followed by adenine nucleotide degradation. As a result, the plasma concentrations of purine bases, such as hypoxanthine (HX), xanthine (Xa), and UA, increase. $(10,11)$ Furthermore, alcohol consumption increases the lactate concentration in the blood, interfering with urinary excretion of UA. ${ }^{(10)}$ Therefore, alcohol consumption results in increased serum UA concentrations. It was reported that allopurinol, is clinically used xanthine oxidase $(\mathrm{XO})$ inhibitor prescribed for gout, seems to be effectively controlling the rapid increase in plasma UA concentrations following beer ingestion. ${ }^{(11)}$ However, few studies have evaluated the potential of food components on UA metabolism after alcohol consumption.

Tea is widely consumed in the world. Although approximately $78 \%$ of the tea production worldwide is black tea, ${ }^{(12)}$ green tea is widely consumed, especially in Asian countries; we primarily focused on green 
tea in this study. Green tea contains polyphenols, particularly catechins. The major catechins present in green tea are catechin (C), epicatechin (EC), epigallocatechin (EGC), epicatechin gallate (ECG) and epigallocatechin gallate (EGCG). It has been reported that green tea polyphenols decrease serum UA concentrations by regulating XO activity and urinary excretion of UA in hyperuricemic mice. ${ }^{(13-15)}$ In addition, green tea extract lowers serum UA concentrations in healthy individuals to some extent. ${ }^{(16)}$ These studies together indicate a role for green tea catechins in UA metabolism. However, these studies evaluated the chronic effect ( $\geq 7$-day ingestion) of green tea catechins, and the acute effect of green tea catechins in UA metabolism remains unclear. Furthermore, a recent meta-analysis showed that green tea consumption was positively associated with serum UA concentrations due to the limited number of studies (three studies). ${ }^{(17)}$ Thus, the effects of green tea remain unclear, and the acute effect of green tea catechins for enhancing the urinary excretion of UA after alcohol ingestion remains to be understood. Since humans do not have a uricase, which is only found as a non-functional pseudogene in the human genome, ${ }^{(18)}$ it is necessary to elucidate the physiological response in human intervention studies.

Therefore, this study aimed to elucidate the acute effect of green tea catechins on UA metabolism after alcohol ingestion.

\section{Materials And Methods}

\section{Subjects}

Ten healthy Japanese men were recruited in this study. Exclusion criteria were liver or renal dysfunction, alcohol dependence, and receiving treatment for hyperuricemia or gout. Subjects who had alcohol intolerance were also excluded. The clinical and biological characteristics of the subjects are shown in Table 1. The mean values \pm standard deviation (SD) of age and body mass index were $25.0 \pm 4.5$ years and $22.1 \pm 2.4 \mathrm{~kg} / \mathrm{m}^{2}$, respectively.

The present study was performed after obtaining written informed consent from all subjects and was approved by the Ethics Committee of the University of Shizuoka and registered with UMIN (UMIN registration number: UMIN000040076). The study was performed in accordance with the Helsinki Declaration.

\section{Study protocol}

We used a randomized crossover study design. The experiment was conducted so that the test days were separated by a washout period of at least 7 days. All the subjects were asked to avoid heavy exercise and any intake of alcohol and purine-rich foods (>200 mg/100 g) for 3 days prior to each study day. All the subjects were instructed to eat from 20:00 to 21:00 h prior to each test day. After an overnight fast, the subjects were provided with the same prescribed foods (breakfast) at 08:00 h and were required to consume breakfast within 20 min. At first visit, the body weight and height were measured. The subjects were instructed to abstain from foods and beverages other than those prescribed from 08:00 $\mathrm{h}$ to 13:00 $\mathrm{h}$. 
The subjects were provided with their test meals (lunch) at 13:00 h and required to consume each test meal within $20 \mathrm{~min}$. During the experimental period, all subjects were instructed to drink water, $100 \mathrm{~mL} / \mathrm{h}$. All subjects underwent a $5 \mathrm{~h}$ urine collection from 13:00 to 18:00 $\mathrm{h}$. Venous blood samples were collected at 15:30 $\mathrm{h}$, which was the mid-point of the $5 \mathrm{~h}$ urine collection.

\section{Test meals}

Two different test meals were used: a Japanese distilled spirit (Shōchū) with water (SW) and Shōchū with catechin-rich green tea (SC). The SW and the SC each contained $20 \mathrm{~g}$ alcohol and were made up to produce a final total volume of $500 \mathrm{~mL}$. We used catechin-rich green tea, which is a commercial beverage, and the SC contained $617 \mathrm{mg}$ of total catechin. All test meals were ingested with $60 \mathrm{~g}$ steamed chicken and $10 \mathrm{~g}$ sesame dressing (Table 2). Steamed chicken contained about $85 \mathrm{mg} / 60 \mathrm{~g}$ purines and Shōchū did not contain purine according to the guidelines for the management of hyperuricemia and gout in Japan. ${ }^{(19)}$

\section{Blood and urine analysis methods and anthropometric measurements}

Blood samples were centrifuged at 2,400 rpm for $10 \mathrm{~min}$ at $4^{\circ} \mathrm{C}$ and separated into serum and stored at $-80^{\circ} \mathrm{C}$ until analysis of serum creatinine (Cre), $\mathrm{UA}, \mathrm{Xa} / \mathrm{Hx}$, aspartate aminotransferase, alanine aminotransferase, $\gamma$-glutamyl transpeptidase, and blood urea nitrogen concentrations. Urine samples were used for analysis of $\mathrm{pH}, \mathrm{Cre}, \mathrm{UA}$, and $\mathrm{Xa} / \mathrm{Hx}$ concentrations. The analyses of serum and urine samples were performed by a blood test company, SRL, Inc. (Tokyo, Japan), except for the analyses of urine $\mathrm{pH}$ and $\mathrm{Xa} / \mathrm{Hx}$ concentrations. The $\mathrm{pH}$ was measured using a portable $\mathrm{pH}$ meter (LAQUA act, D-71, Horiba Scientific, Kyoto, Japan). The concentration of $\mathrm{Xa} / \mathrm{Hx}$ was measured using a $\mathrm{Xa} / \mathrm{Hx}$ colorimetric assay kit (Bio Vision, USA). Anthropometric measurements were determined using a bioelectrical impedance analysis method (innerscan DUAL RD-909, TANITA Corporation, Tokyo, Japan). Height was measured using a stadiometer.

\section{Calculating formulas}

We calculated the creatinine clearance $(\mathrm{Ccr})$, filtered UA load $\left(\mathrm{F}_{\cup A}\right)$, UA clearance $\left(\mathrm{C}_{U A}\right)$, urinary UA excretion per kilogram of body weight per hour (U-UA excretion), and renal fractional UA excretion ( $\left.F E_{U A}\right)$ using the following formulas ( $U$ denotes urine, $S$ denotes serum, BSA denotes body surface area, and BW

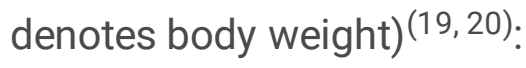

$\mathrm{Ccr}=\mathrm{U}$-volume $\times \mathrm{U}-$ Cre $/(\mathrm{S}-$-Cre $\times \mathrm{min}) \times 1.73 / \mathrm{BSA}$

$F_{U A}=(S-U A / 100) \times C C r$

$\mathrm{C}_{\mathrm{UA}}=\mathrm{U}$-volume $\times \mathrm{U}-\mathrm{UA} /(\mathrm{S}-\mathrm{UA} \times \mathrm{min}) \times 1.73 / \mathrm{BSA}$

U-UA excretion $=$ U-UA $\times($ U-volume/100 $) / \mathrm{BW} / \mathrm{h}$ 
$\mathrm{FE}_{\mathrm{UA}}=(\mathrm{U}-\mathrm{UA} \times \mathrm{S}-\mathrm{Cre}) /(\mathrm{U}-\mathrm{Cre} \times \mathrm{S}-\mathrm{UA}) \times 100$

We also calculated filtered $\mathrm{Xa} / \mathrm{Hx}$ load $\left(\mathrm{F}_{\mathrm{Xa} / \mathrm{Hx}}\right), \mathrm{Xa} / \mathrm{Hx}$ clearance $\left(\mathrm{C}_{\mathrm{X} a / H \mathrm{H}}\right)$, urinary $\mathrm{Xa} / \mathrm{Hx}$ excretion per kilogram of body weight per hour ( $\mathrm{U}-\mathrm{Xa} / \mathrm{Hx}$ excretion), and renal fractional $\mathrm{Xa} / \mathrm{Hx}$ excretion $\left(\mathrm{FE}_{\mathrm{Xa} / \mathrm{Hx}}\right)$ using the following formulas:

$\mathrm{F}_{\mathrm{Xa} / \mathrm{Hx}}=\mathrm{S}-\mathrm{Xa} / \mathrm{Hx} \times \mathrm{Ccr}$

$\mathrm{C}_{\mathrm{Xa} / \mathrm{Hx}}=\mathrm{U}-$ volume $\times \mathrm{U}-\mathrm{Xa} / \mathrm{Hx} /(\mathrm{S}-\mathrm{Xa} / \mathrm{Hx} \times \mathrm{min}) \times 1.73 / \mathrm{BSA}$

$\mathrm{U}-\mathrm{Xa} / \mathrm{Hx}$ excretion $=(\mathrm{U}-\mathrm{Xa} / \mathrm{Hx} / 1000) \times \mathrm{U}$-volume $/ \mathrm{BW} / \mathrm{h}$

$\mathrm{FE}_{\mathrm{Xa} / \mathrm{Hx}}=(\mathrm{U}-\mathrm{Xa} / \mathrm{Hx} \times \mathrm{S}-\mathrm{Cre}) /(\mathrm{U}-\mathrm{Cre} \times \mathrm{S}-\mathrm{Xa} / \mathrm{Hx}) \times 100$

\section{Statistical analysis}

All data are shown as means \pm SD. The Shapiro-Wilk statistic was used for data normality testing. Parametric analysis was used for normal distribution data, and non-parametric analysis was used for data exhibiting a non-normal distribution. Differences between the SW and SC groups were identified using a paired $t$-test or the Wilcoxon signed-rank test. Probability $(P)$ values less than 0.05 were considered statistically significant in all analyses. Statistical analyses were performed using SPSS for Windows, release 26.0 (SPSS, Chicago, IL).

\section{Results}

\section{Serum UA and $\mathrm{Xa} / \mathrm{Hx}$ concentrations}

The S-UA concentration in the SW group was $6.3 \pm 1.0 \mathrm{mg} / \mathrm{dL}$, and in the SC group, it was $6.3 \pm 0.9$ $\mathrm{mg} / \mathrm{dL}$. The S-Xa/Hx concentration in the $\mathrm{SW}$ group was $11.7 \pm 12.7 \mathrm{mg} / \mathrm{mL}$, whereas $11.4 \pm 12.2 \mathrm{mg} / \mathrm{mL}$ in the SC group. No significant differences were observed in S-UA and S-Xa/Hx concentrations between the two groups.

\section{Urinary volume and $\mathrm{pH}$}

Urinary volume in the SW group was $848 \pm 157 \mathrm{~mL}$, whereas $991 \pm 252 \mathrm{~mL}$ in the SC group. Urinary pH in the SW group was $6.5 \pm 0.2$, and in the SC group, it was $6.5 \pm 0.3$. No significant differences in urinary volume and $\mathrm{pH}$ were observed between the two groups.

\section{Renal UA metabolic indices}

Renal UA metabolic indices are shown in Fig. 1. $F_{\text {UA }}$ did not differ significantly between the SW and SC groups (Fig. 1A). U-UA excretion in the SC was significantly higher than in the SW group (SW, $0.45 \pm 0.08$; $\mathrm{SC}, 0.52 \pm 0.09 \mathrm{mg} / \mathrm{kg} / \mathrm{h} ; P<0.05)$ (Fig. 1C). Although $\mathrm{C}_{\mathrm{UA}}$ and $\mathrm{FE}_{\mathrm{UA}}$ did not differ significantly between 
the SW and SC groups, $\mathrm{C}_{\mathrm{UA}}$ and $\mathrm{FE}_{\mathrm{UA}}$ were slightly higher in the SC group than in the SW group $\left(\mathrm{C}_{\mathrm{UA}}: \mathrm{SW}\right.$, $7.76 \pm 2.14 ; \mathrm{SC}, 8.75 \pm 2.23 \mathrm{~mL} / \mathrm{min} / 1.73 \mathrm{~m}^{2} ; P=0.054 ; \mathrm{FE}_{\mathrm{UA}}: \mathrm{SW}, 6.08 \pm 1.36 ; \mathrm{SC}, 6.64 \pm 1.42 \% ; P=$ 0.060) (Fig. 1B, D).

\section{Renal $\mathrm{Xa} / \mathrm{Hx}$ metabolic indices}

Renal $\mathrm{Xa} / \mathrm{Hx}$ metabolic indices are shown in Fig. 2. No significant differences in $\mathrm{F}_{\mathrm{Xa} / \mathrm{Hx}}, \mathrm{C}_{\mathrm{Xa} / \mathrm{Hx}}$ and $\mathrm{FE}_{\mathrm{Xa} / \mathrm{Hx}}$ were observed between the SW and SC groups (Fig. 2A, B, D). U-Xa/Hx excretion in the SC group was significantly higher than in the SW group (SW, $0.08 \pm 0.04 ; S C, 0.16 \pm 0.05 \mathrm{mg} / \mathrm{kg} / \mathrm{h} ; P<0.01$ ) (Fig. 2C).

\section{Discussion}

In the present study, we investigated the acute effect of green tea catechins on UA metabolism after alcohol ingestion. We showed that U-UA and U-Xa/Hx excretions in the test individuals receiving Shōchū with catechin-rich green tea (SC group) were significantly higher than in those who received Shōchū with water (SW group). $\mathrm{C}_{\mathrm{UA}}$ and $\mathrm{FE}_{\mathrm{UA}}$ in the $\mathrm{SC}$ group were slightly higher than in the $\mathrm{SW}$ group but not significantly so.

Hyperuricemia is defined as a S-UA concentration higher than $7.0 \mathrm{mg} / \mathrm{dL}$. The S-UA concentration is tightly regulated by UA reabsorption and excretion in the kidney, and various urate transporters mediate UA reabsorption and excretion. ${ }^{21)}$ Urate anion transporter 1 (URAT1), which transports UA across the apical membrane of proximal tubule cells, is the major urate reabsorption transporter. The organic anion transporters (OAT) 1 and OAT3 are localized at the basolateral side of the proximal tubular epithelial cells membrane and play an important role in UA excretion. Ethanol ingestion increases the concentration of lactate in the blood, ${ }^{(10,11)}$ and lactate reportedly reduces renal excretion of UA by competing for OAT1 and OAT3 with UA. ${ }^{(21)}$ In addition, lactate accelerates the reabsorption of UA in the renal epithelial cells via URAT1. ${ }^{(22)}$ In contrast, it was reported that green tea polyphenols reduce URAT1 expression and increase OAT1 and OAT3 expressions in the kidney of hyperuricemic mice. ${ }^{(13)}$ In this study, we observed an increase of U-UA excretion in the SC group. Accordingly, our result suggested that green tea catechins might increase U-UA excretion through increasing UA clearance via urate transporters, even though alcohol was ingested.

$\mathrm{XO}$ is the key enzyme that produces UA. Previously, green tea polyphenols dose-dependently decreased $X O$ activity in the liver of the hyperuricemic mice. ${ }^{(13-15)}$ It was also reported that the consumption of green tea inhibited the increase in plasma $\mathrm{XO}$ activity induced by exercise in weight-trained men. ${ }^{(23)}$ In this study, $\mathrm{U}-\mathrm{Xa} / \mathrm{Hx}$ excretions were significantly higher in the SC group than in the SW group, indicating that the increase in $\mathrm{U}-\mathrm{Xa} / \mathrm{Hx}$ excretion in the SC group might be due to the effect of green tea catechins on XO activity, although we could not measure XO activity directly. 
Although we did not directly measure plasma catechin concentrations, several previous studies reported that plasma catechin concentrations are elevated within 1-2 $\mathrm{h}$ after intake of green tea. ${ }^{(24-26)}$ This could suggest that the promoting effect on UA and $\mathrm{Xa} / \mathrm{Hx}$ excretions in the SC group was due to green tea catechins.

There was a trend toward urinary volume being higher in the SC group than in the SW group $(P=0.073)$. During the experimental period, all subjects were instructed to drink water, $100 \mathrm{~mL} / \mathrm{h}$, and so the total fluid intake was equal. Previous studies suggested that a diuretic response to caffeine-containing drinks is likely to occur in response to an acute dose of caffeine of about $300 \mathrm{mg}$ or more, being unlikely, however, at doses of about $250 \mathrm{mg}$ or less. ${ }^{(27)}$ In addition, it was reported that a caffeine intake of $6 \mathrm{mg} / \mathrm{kg}$ in the form of coffee can induce an acute diuretic effect, whereas $3 \mathrm{mg} / \mathrm{kg}$ does not disturb the fluid balance in healthy adults. ${ }^{(28)}$ The catechin-rich green tea used in this study contained $91.4 \mathrm{mg}$ caffeine (equivalent to one cup of coffee), which is a lower dose than used in previous studies. ${ }^{27,28)}$ Hence, these results suggested that the increase in U-UA excretion in the SC group was due to the effect of green tea catechins and not the effect of caffeine.

No significant differences were observed between the two groups regarding S-UA and S-Xa/Hx concentrations. In this study, venous blood samples were collected only at $150 \mathrm{~min}$ after ingestion of test meal, which is the mid-point of the $5 \mathrm{~h}$ urine collection. A previous report showed that plasma concentrations of UA, HX, and Xa peak at 30 or 90 min after beer ingestion $(10 \mathrm{~mL} / \mathrm{kg} \text { body weight })^{(11)}$ Thus, we were not able to observe the peak values in S-UA and S-Xa/Hx concentrations.

Several limitations of our study should be considered. We did not examine the effect of water ingestion, which could have been done by adding a control group. To determine the effect of green tea catechins on UA metabolism, it is necessary to examine the effect of water ingestion and monitor the time course of serum and urinary $\mathrm{UA}, \mathrm{HX}, \mathrm{Xa}$, and catechin concentrations. Another limitation of this study is that women are not included in this study. It is well known that gout affects men more than women and there is a sex difference in S-UA concentrations ${ }^{(29)}$; thus, we decided to include only men as the study population. However, S-UA concentrations are known to increase in women after menopause, ${ }^{(29)}$ and the effects in women should be evaluated as well. Furthermore, we must take into account the small sample size in this study. A larger cohort is clearly required to determine the effect of green tea catechins. Finally, we used catechin-rich green tea, which is equivalent to five cups of regular green tea. Therefore, it is necessary to investigate whether the effect of green tea catechins can be dose-dependently observed for regular green tea.

This study showed significantly higher U-UA and U-Xa/Hx excretions in healthy men receiving Shōchū with catechin-rich green tea than in those receiving Shōchū with water. In conclusion, this study illustrates the potential of green tea catechins to enhance the excretion of $\mathrm{UA}$ and $\mathrm{Xa} / \mathrm{Hx}$, even when alcohol is ingested simultaneously. It is important to limit excessive alcohol intake for hyperuricemia; however, it is necessary to account for the non-adherence of limiting alcohol intake. This study demonstrates the 
potential clinical applications of catechin-rich green tea as a dietary component for continued dietary therapy.

\section{Declarations}

\section{Acknowledgments}

This study was supported by a Grant-in-Aid for Scientific Research (C) 19K11670 from the Ministry of Education, Culture, Sports, Science and Technology in Japan (awarded to HA).

\section{Conflict of Interest}

The authors declare that they have no competing interests.

\section{Author Contributions}

YK and HA conceived the research idea and designed the study. YK, AY, MH, MA, and TA collected, analyzed, and interpreted the data. YK and AY drafted the manuscript. TA and TH contributed significant advice. HA edited the manuscript. All the authors contributed to revisions of the manuscript and reviewed the final version.

\section{Abbreviations}

ATP binding cassette subfamily G member 2: ABCG 2; UA: uric acid; XO: xanthine oxidase; SD: standard deviation; SW: Shōchū with water; SC: Shōchū with catechin-rich green tea; Cre: creatinine; $\mathrm{Xa} / \mathrm{Hx}$ : xanthine/hypoxanthine; $\mathrm{Ccr}$ : creatinine clearance; $\mathrm{F}_{\mathrm{UA}}$ : filtered uric acid load; $\mathrm{C}_{\mathrm{UA}}$ : uric acid clearance; $\mathrm{U}-$ $\mathrm{UA}$ excretion: urinary uric acid excretion per kilogram of body weight per hour; $\mathrm{FE}_{\mathrm{UA}}$ : renal fractional uric acid excretion; $\mathrm{F}_{\mathrm{Xa} / \mathrm{Hx}}$ : filtered $\mathrm{Xa} / \mathrm{Hx}$ load; $\mathrm{C}_{\mathrm{Xa} / \mathrm{Hx}}: \mathrm{Xa} / \mathrm{Hx}$ clearance; $\mathrm{U}-\mathrm{Xa} / \mathrm{Hx}$ excretion: urinary $\mathrm{Xa} / \mathrm{Hx}$ excretion per kilogram of body weight per hour; $\mathrm{FE}_{\mathrm{Xa} / \mathrm{Hx}}$ : renal fractional $\mathrm{Xa} / \mathrm{Hx}$ excretion; URAT1: urate anion transporter 1; OAT: organic anion transporters.

\section{References}

1. Ministry of Health, Labour and Welfare. The outline of the results of National Livelihood Survey 2016. https://www.mhlw.go.jp/toukei/saikin/hw/k-tyosa/k-tyosa16/index.html

2. Jalal DI, Chonchol M, Chen W, Targher G. Uric acid as a target of therapy in CKD. Am J Kidney Dis 2013; 61: 134-146.

3. Niskanen LK, Laaksonen DE, Nyyssönen K, et al. Uric acid level as a risk factor for cardiovascular and all-cause mortality in middle-aged men: a prospective cohort study. Arch Intern Med 2004; 164: 1546-1551. 
4. Choi HK, Ford ES. Prevalence of the metabolic syndrome in individuals with hyperuricemia. $A m \mathrm{~J}$ Med 2007; 120: 442-447.

5. Zhang W, Iso H, Murakami Y, et al. Serum Uric Acid and Mortality Form Cardiovascular Disease: EPOCH-JAPAN Study. J Atheroscler Thromb 2016; 23: 692-703.

6. Uedono $\mathrm{H}$, Tsuda A, Ishimura E, et al. U-shaped relationship between serum uric acid levels and intrarenal hemodynamic parameters in healthy subjects. Am J Physiol Renal Physiol 2017; 312: F992-F997.

7. Choi HK. A prescription for lifestyle change in patients with hyperuricemia and gout. Curr Opin Rheumatol 2010; 22: 165-172.

8. Rho YH, Zhu Y, Choi HK. The epidemiology of uric acid and fructose. Semin Nephrol 2011; 31: 410419.

9. Wang M, Jiang X, Wu W, Zhang D. A meta-analysis of alcohol consumption and the risk of gout. Clin Rheumatol 2013; 32: 1641-1648.

10. Yamamoto T, Moriwaki Y, Takahashi S. Effect of ethanol on metabolism of purine bases (hypoxanthine, xanthine, and uric acid). Clin Chim Acta 2005; 356: 35-57.

11. Ka T, Moriwaki Y, Inokuchi $T$, et al. Effects of allopurinol on beer-induced increases in plasma concentrations and urinary excretion of purine bases (uric acid, hypoxanthine, and xanthine). Horm Metab Res 2006; 38: 188-192.

12. Sang S, Lambert JD, Ho CT, Yang CS. The chemistry and biotransformation of tea constituents. Pharmacol Res 2011; 64: 87-99.

13. Chen G, Tan ML, Li KK, Leung PC, Ko CH. Green tea polyphenols decreases uric acid level through xanthine oxidase and renal urate transporters in hyperuricemic mice. J Ethnopharmacol 2015; 175: $14-20$.

14. Zhu C, Xu Y, Liu ZH, Wan XC, Li DX, Tai LL. The anti-hyperuricemic effect of epigallocatechin-3gallate (EGCG) on hyperuricemic mice. Biomed Pharmacother 2018; 97: 168-173.

15. Li F, Liu Y, Xie Y, Liu Z, Zou G. Epigallocatechin gallate reduces uric acid levels by regulating xanthine oxidase activity and uric acid excretion in vitro and in vivo. Ann Palliat Med 2020; 9: 331-338.

16. Jatuworapruk K, Srichairatanakool S, Ounjaijean S, Kasitanon N, Wangkaew S, Louthrenoo W. Effects of green tea extract on serum uric acid and urate clearance in healthy individuals. $J$ Clin Rheumatol 2014; 20: 310-313.

17. Zhang Y, Cui Y, Li XA, et al. Is tea consumption associated with the serum uric acid level, hyperuricemia or the risk of gout? A systematic review and meta-analysis. BMC Musculoskelet Disord 2017; 18: 95.

18. Wu XW, Muzny DM, Lee CC, Caskey CT. Two independent mutational events in the loss of urate oxidase during hominoid evolution. J Mol Evol 1992; 34: 78-84.

19. Japanese Society of Gout and Nucleic Acid Metabolism Guideline Revisory Committee, ed. Revised Guideline for the Management of Hyperuricemia and Gout. Tokyo: Shindan To Chiyo Sha Co Ltd; 
2019 (in Japanese)

20. Perez-Ruiz F, Calabozo M, Erauskin GG, Ruibal A, Herrero-Beites AM. Renal underexcretion of uric acid is present in patients with apparent high urinary uric acid output. Arthritis Rheum 2002; 47: 610-613.

21. Xu L, Shi Y, Zhuang S, Liu N. Recent advances on uric acid transporters. Oncotarget 2017; 8: 100852100862.

22. Enomoto A, Kimura H, Chairoungdua A, et al. Molecular identification of a renal urate anion exchanger that regulates blood urate levels. Nature 2002; 417: 447-452.

23. Panza VS, Wazlawik E, Ricardo Schütz G, Comin L, Hecht KC, da Silva EL. Consumption of green tea favorably affects oxidative stress markers in weight-trained men. Nutrition 2008; 24: 433-442.

24. Takahashi M, Miyashita M, Suzuki K, et al. Acute ingestion of catechin-rich green tea improves postprandial glucose status and increases serum thioredoxin concentrations in postmenopausal women. Br J Nutr 2014; 112: 1542-1550.

25. Van Amelsvoort JM, Van Hof KH, Mathot JN, Mulder TP, Wiersma A, Tijburg LB. Plasma concentrations of individual tea catechins after a single oral dose in humans. Xenobiotica 2001; 31 : 891-901.

26. Rietveld A, Wiseman S. Antioxidant effects of tea: evidence from human clinical trials. J Nutr 2003; 133: 3285S-3292S.

27. Maughan RJ, Griffin J. Caffeine ingestion and fluid balance: a review. J Hum Nutr Diet 2003; 16: 411420.

28. Seal AD, Bardis CN, Gavrieli A, et al. Coffee with High but Not Low Caffeine Content Augments Fluid and Electrolyte Excretion at Rest. Front Nutr 2017; 4: 40.

29. Akizuki S. Serum uric acid levels among thirty-four thousand people in Japan. Ann Rheum Dis 1982; 41: $272-274$.

\section{Tables}


Table 1. Characteristics of the subjects

(Mean $\pm \mathrm{SD}, 10$ men).

\begin{tabular}{lcccc}
\hline & & mean & \pm & SD \\
\hline Age & $(\mathrm{year})$ & 25.0 & \pm & 4.5 \\
Height & $(\mathrm{cm})$ & 174.2 & \pm & 7.0 \\
Body weight & $(\mathrm{kg})$ & 67.1 & \pm & 8.7 \\
BFP & $(\%)$ & 19.0 & \pm & 4.1 \\
BMI & $\left(\mathrm{kg} / \mathrm{m}^{2}\right)$ & 22.1 & \pm & 2.4 \\
HbAlc & $(\%)$ & 5.1 & \pm & 0.2 \\
TG & $(\mathrm{mg} / \mathrm{dL})$ & 70.3 & \pm & 33.8 \\
LDL-C & $(\mathrm{mg} / \mathrm{dL})$ & 96.5 & \pm & 22.1 \\
HDL-C & $(\mathrm{mg} / \mathrm{dL})$ & 63.2 & \pm & 12.8 \\
AST & $(\mathrm{U} / \mathrm{L})$ & 21.9 & \pm & 5.1 \\
ALT & $(\mathrm{U} / \mathrm{L})$ & 21.6 & \pm & 8.2 \\
$\gamma$-GTP & $(\mathrm{U} / \mathrm{L})$ & 23.1 & \pm & 6.8 \\
BUN & $(\mathrm{mg} / \mathrm{dL})$ & 14.0 & \pm & 2.2 \\
Cre & $(\mathrm{mg} / \mathrm{dL})$ & 0.93 & \pm & 0.13 \\
e-GFR & $\left(\mathrm{mL} / \mathrm{min} / \mathrm{l} .73 \mathrm{~m}^{2}\right)$ & 85.5 & \pm & 13.3 \\
UA & $(\mathrm{mg} / \mathrm{dL})$ & 6.0 & \pm & 1.0 \\
\hline
\end{tabular}

BFP, body fat percentage; BMI, body mass index; HbAlc, hemoglobin A 1c; TG, triglyceride; LDL-C, low-density lipoprotein cholesterol; HDL-C, high-density lipoprotein cholesterol; AST, aspartate aminotransferase; ALT, alanine aminotransferase; $\gamma$-GTP, $\gamma$-glutamyl transpeptidase; BUN, blood urea nitrogen; Cre, creatinine; e-GFR, estimated glomerular filtration rate; UA, uric acid.

Table 2. Composition of the test meals.

\begin{tabular}{|c|c|c|c|c|c|c|c|c|}
\hline & $\begin{array}{c}\text { Serving size } \\
\text { (g) }\end{array}$ & $\begin{array}{c}\text { Energy } \\
\text { (kcal) }\end{array}$ & $\begin{array}{c}\text { Protein } \\
\text { (g) }\end{array}$ & $\begin{array}{l}\text { Fat } \\
(\mathrm{g}) \\
\end{array}$ & $\begin{array}{c}\text { Carbohydrate } \\
\text { (g) }\end{array}$ & $\begin{array}{c}\text { Sodium } \\
\text { (mg) }\end{array}$ & $\begin{array}{c}\text { Catechin } \\
(\mathrm{mg})\end{array}$ & $\begin{array}{c}\text { Alcohol } \\
\text { (g) }\end{array}$ \\
\hline \multicolumn{9}{|l|}{ Shōchū with water (SW) } \\
\hline Water & 400 & 0 & 0 & 0 & 0 & 0 & 0 & 0 \\
\hline Barely liquor & 100 & 146 & 0 & 0 & 0 & 0 & 0 & 20 \\
\hline Chicken & 60 & 63 & 13.2 & 1.0 & 0.3 & 433 & 0 & 0 \\
\hline Sesame dressing & 10 & 9 & 0.2 & 0.2 & 1.5 & 158 & 0 & 0 \\
\hline Total & 570 & 218 & 13.4 & 1.2 & 1.8 & 591 & 0 & 20 \\
\hline \multicolumn{9}{|c|}{ Shōchū with catechin-rich green tea (SC) } \\
\hline High catechin green tea & 400 & 16 & 0 & 0 & $4.5^{*}$ & 39 & 617 & 0 \\
\hline Barely liquor & 100 & 146 & 0 & 0 & 0 & 0 & 0 & 20 \\
\hline Chicken & 60 & 63 & 13.2 & 1.0 & 0.3 & 433 & 0 & 0 \\
\hline Sesame dressing & 10 & 9 & 0.2 & 0.2 & 1.5 & 158 & 0 & 0 \\
\hline Total & 570 & 234 & 13.4 & 1.2 & 6.3 & 630 & 617 & 20 \\
\hline
\end{tabular}

* Contains cyclic oligosaccharides as taste-masking agent. 


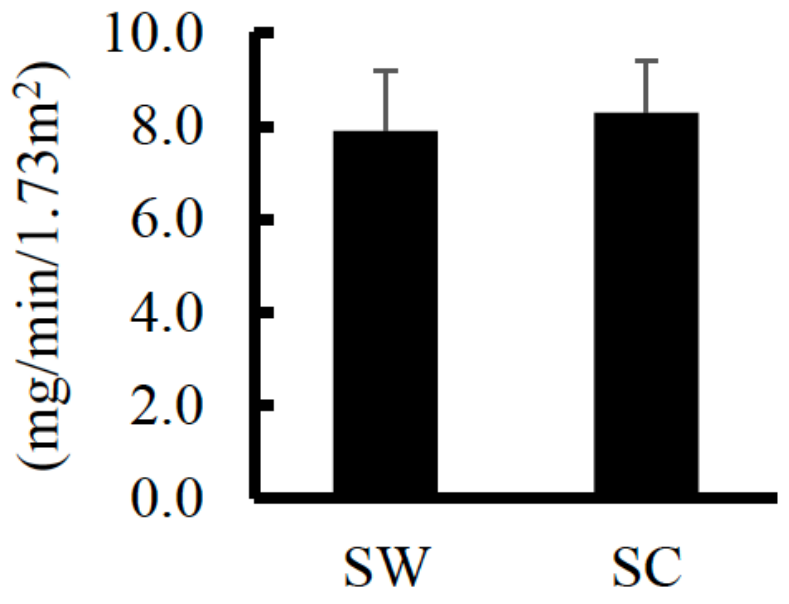

(C) U-UA excretion

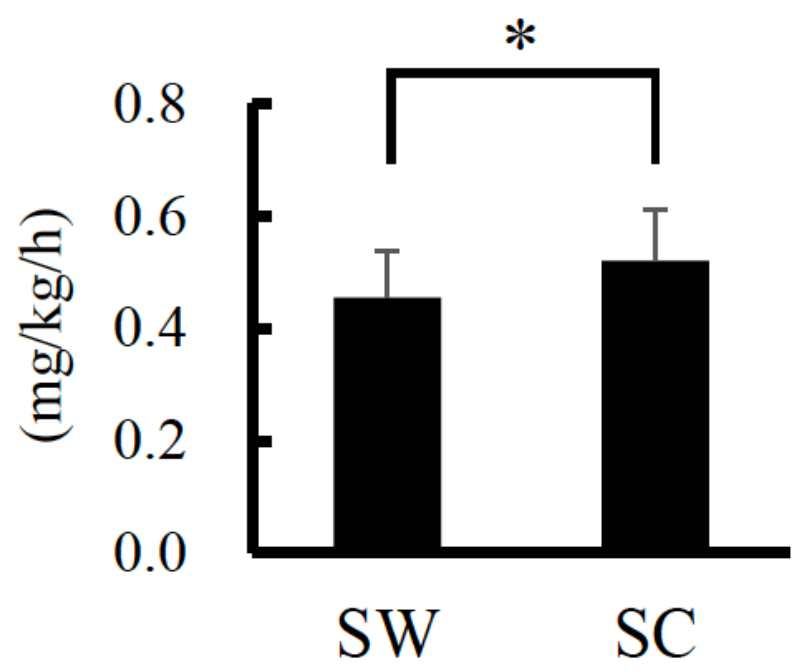

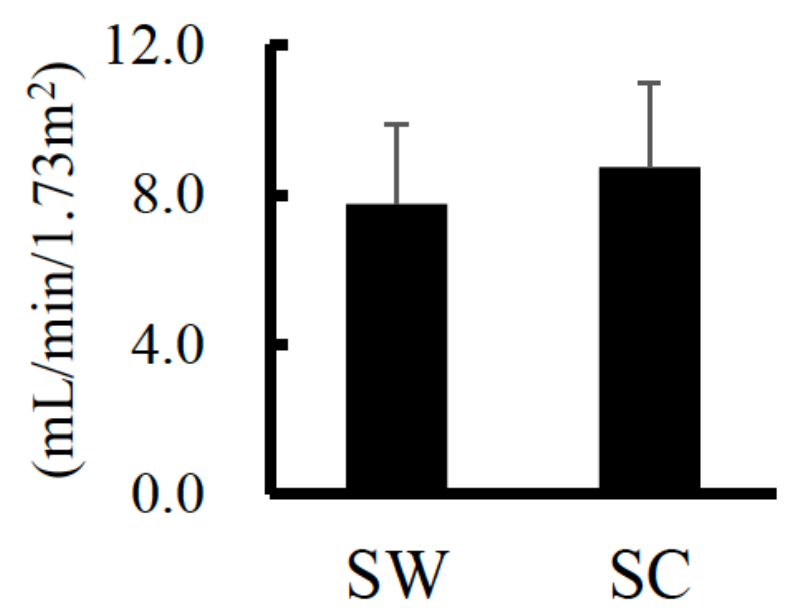

(D) FEuA

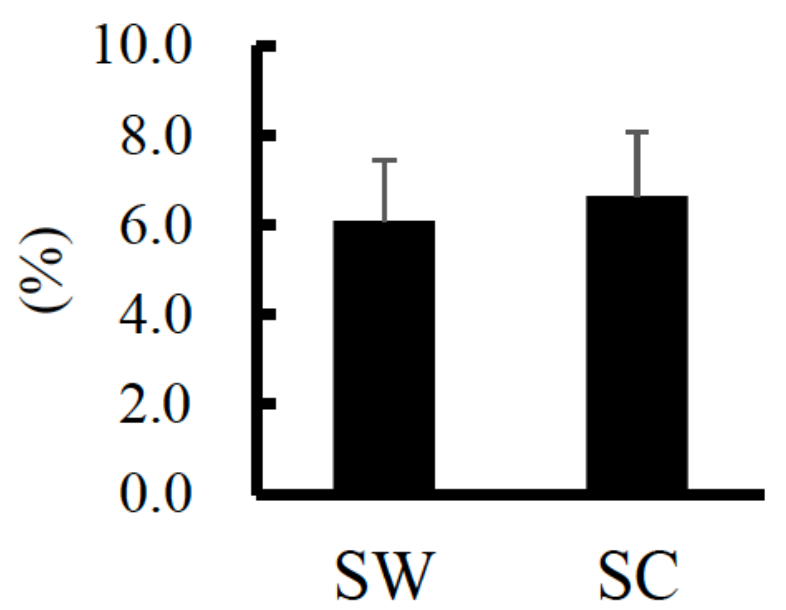

Figure 1

Uric acid metabolic indices (A) Filter load of uric acid, FUA; (B) uric acid clearance, CUA; (C) urinary uric acid excretion per kilogram of body weight per hour, U-UA excretion; (D) renal fractional excretion of uric acid, FEUA. SW, Shōchū with water; SC, Shōchū with catechin-rich green tea. Values are means \pm SD represented by vertical bars. Differences $(P<0.05)$ between the SW and SC groups were identified using the paired t-test or Wilcoxon signed-rank test: * SW vs. SC. 
(A) $\mathrm{Fxa} / \mathrm{Hx}$

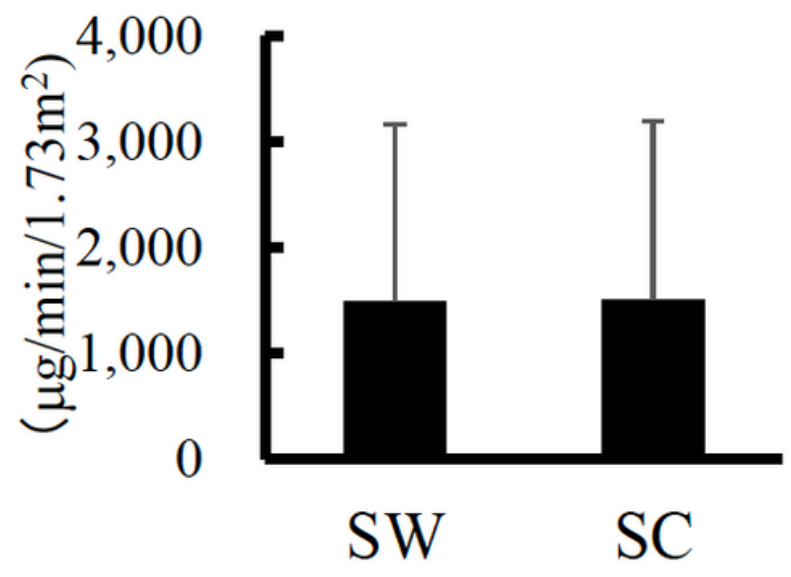

(C) U-Xa/Hx excretion

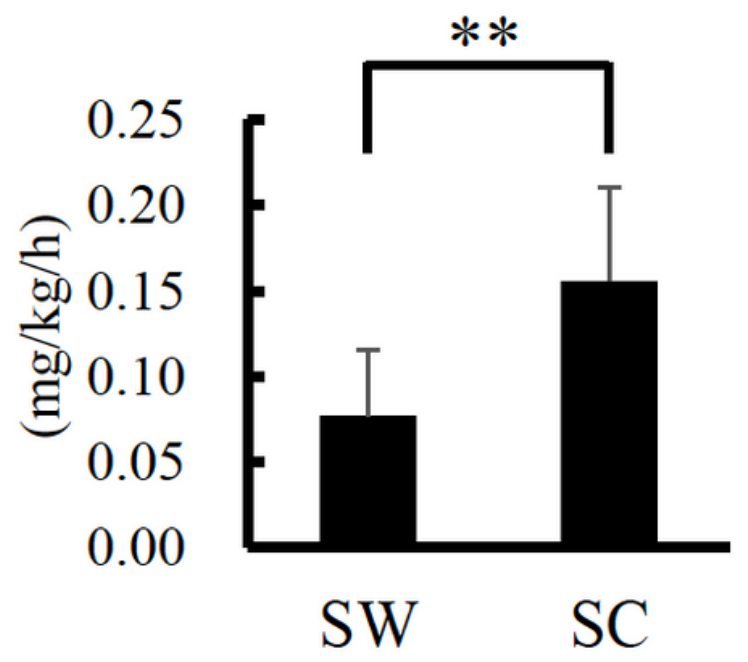

(B) $\mathrm{CXa} / \mathrm{Hx}$

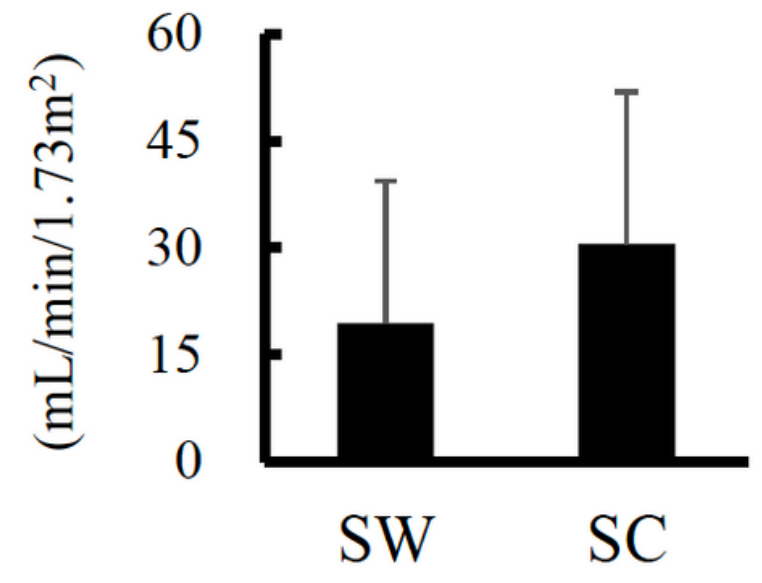

(D) $\mathrm{FExa} / \mathrm{Hx}$

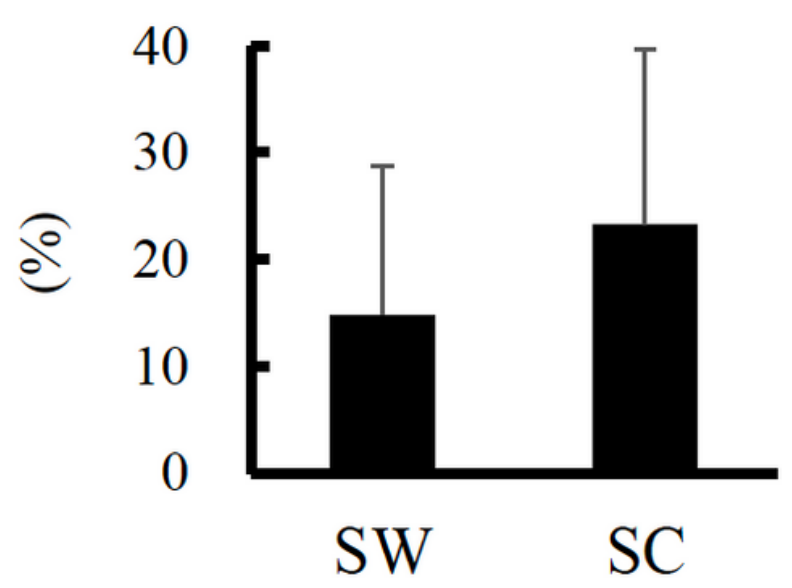

Figure 2

Xanthine/hypoxanthine metabolic indices (A) Filter load of xanthine/hypoxanthine, FXa/Hx; (B) xanthine/hypoxanthine clearance, $\mathrm{CXa} / \mathrm{Hx}$; (C) urinary xanthine/hypoxanthine excretion per kilogram of body weight per hour, U-Xa/Hx excretion; (D) renal fractional excretion of xanthine/hypoxanthine, FEXa/Hx. SW, Shōchū with water; SC, Shōchū with catechin-rich green tea. Values are means \pm SD represented by vertical bars. Differences $(P<0.01)$ between the SW and SC groups were identified using the paired t-test or Wilcoxon signed-rank test: ** SW vs. SC. 